\section{A Clear and Present Danger}

\author{
Murray McQuigge, MD
}

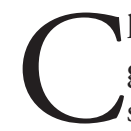
lean drinking water. It is something that the public has pretty much taken for granted for the past hundred years. The public has little idea and, perhaps understandably, little interest, in the many people and agencies struggling daily to ensure that drinking water remains uncontaminated. But our environment is changing, new pathogens are emerging, drinking water systems are aging, and governments seem more interested in ensuring business in the global marketplace than in ensuring the safety and health of its citizens.

In Canada, Public Health was established in the late 1800s in response to people's concerns about disease spread by contaminated drinking water. Chlorination of drinking water started early in the 1900s and was readily accepted because of the quick and visible reduction of disease when it was instituted. But Public Health is often the victim of its own successes: when things go well, the public doesn't see the disease we prevent. Interest and funding decrease and the public assumes that uncontaminated drinking water is the natural order of things rather than something that needs to be constantly monitored, trained for, and maintained.

In this issue of the CJPH, the article on the survey of British Columbia's drinking water during 1997-981 substantiates the concerns that have been discussed during the Inquiries of the Walkerton and North Battleford waterborne outbreaks of disease. To name a few: lack of a protected water supply, potential sources of pollution in the watershed area, lack of primary disinfection, lack of training programs in over half of water system operations, and potential routes of pollution into groundwater from abandoned wells.

Our environment is changing and we can no longer trust that our water sources will remain, or are, pristine. There are now some 6.2 billion people on this planet that, the experts tell us, can only sustain a maximum of 4 billion people. Human, agricultural, and industrial wastes are increasing. These same wastes are finding their way into our groundwater and put it at bacterial, viral, and chemical risk. New, deadly pathogens like E. coli 0157:H7 are emerging to threaten our water supplies. In Ontario and elsewhere in Canada, $30-40 \%$ of private wells routinely fall short of standards for potability. ${ }^{2}$ Water is a common resource and should be regulated as such. That means that both public and private water usages should be included in the overall management of our water.

\section{Current problems}

E. coli 0157:H7 was discovered in 1982. This new pathogen, carried mainly in cattle in North America, is showing up increasingly in our food, and now the Walkerton waterborne disaster has shown that, with the right conditions, it can wreak havoc in a drinking water system. E. coli 0157:H7 will not be the last of new pathogens to threaten our drinking water. That is why it is so important to have training programs for water operators and an ongoing program to update that training to encompass new developments in technology and emerging health threats. Water operators need to be able to share experiences and learn from recent waterborne outbreaks.

Many municipalities have aging water distribution systems. Old pipes, lack of new treatment technology, inadequate water testing protocols, and lack of adequate staff training make a waterborne disaster more likely. Such deficiencies will be expensive to resolve. It will take considerable political will and courage to tackle these issues. The public will have to be convinced of the need for adequate funding, and educated on the real cost of infra-

Medical Officer of Health, Grey Bruce Health Unit, Owen Sound, ON structure, surveillance, and maintenance needed to ensure safe drinking water.

Aging systems often mean an increase in biofilm in the pipes. Biofilms are the cells immobilized at a substratum and frequently embedded in an organic polymer matrix of microbial origin. ${ }^{3}$ The definition of biofilms is a work in progress because of their enormous diversity. In plainer language, biofilm in the inside of water pipes is the accumulated sludge made up of corrosion products from the pipes and colonies of bacteria, viruses and algae. Biofilm science is new and fascinating. Bacteria in biofilms get organized and can exhibit unique properties. E. coli 0157:H7 for instance, is up to 2400 times more resistant to chlorine in biofilms than when floating free in water. ${ }^{4}$ Once established, biofilms are difficult to remove. Stay tuned. You will hear a great deal more about biofilms in the coming months and years.

Water testing is expensive, not because the tests are expensive, but because multiple tests need to be done per week to ensure that the drinking water system is operating efficiently and to show current trends in possible contamination. In Ontario in 1996, drinking water testing was given over to the private sector labs. Municipalities were reluctant to assume this increased cost and there is some evidence that some water testing was reduced or ignored because of the cost. Public health units lost the close communication on water tests that they had established with government labs.

A discussion needs to take place about the role of government in protecting our health and safety. I believe that government services have been pared down to the point that the safety of the public is at risk. Surely the one business that government should be in is that of protecting the health and safety of the population. It will be ironic if Canada is able to compete well in the global marketplace but, in order to compete, has reduced public safety measures to the point where the health of Canada's working force is put at risk.

\section{Future scenarios}

Prevention is the key to safe drinking water. By the time a water test is reported as contaminated, it is far too late. The public has already consumed the water and is at risk. Drinking water sources need to 
be secure, the appropriate monitors and alarms need to be on a drinking water system, and appropriate treatment and backups in place.

We should start with the premise that we should not be putting our waste into our water and then look for solutions to make that possible.

Two new books bear on the subject: Mark DeVilliers' book titled simply "Water" and Laurie Garrett's book entitled "Betrayal of Trust: The Collapse of Global Public Health”. De Villiers' book details the fate of water around the world. There is too little drinking water for too many people. Conflicts will arise about the issue of ownership and accessibility to drinking water. And we are quickly polluting the drinking water that does exist. Garrett's book documents the declining resources being put into public health worldwide. She discusses the resulting outbreaks and risks now present because of government lack of support for basic Public Health surveillance and interventions.

In summary, because of a variety of factors, we can no longer trust our drinking water sources. The cornerstone of Public Health is safe drinking water. The world is changing and we need to reeducate the public and government on the importance of good water distribution systems, the training of water operators, Public Health's role in surveillance and response to water problems, and the need to protect our watersheds. Governments need to be convinced of the need for a balance between its role of encouraging business and that of protecting the health and safety of its citizens. Last, we need to reexamine why we put our wastes into water in the first place. To continue to do so will only worsen the already deteriorating quality of our drinking water.

\section{REFERENCES/RÉFÉRENCES}

1. van Netten C, Pereira R, Brands R. Drinking water supply and management practices in British Columbia, 1997-98. Can J Public Health 2002;93(1)14-18

2. Raina P, Pollari F, Teare G, Goss M, Barry D, Wilson J. The relationship between E. coli indicator bacteria in well-water and gastrointestinal illnesses in rural families. Can J Public Health 1999;90(3):172-75. (plus anecdotal evidence from discussions with Health Units across Canada.)

3. Percival S, Walter J, Hunter P. Microbiological Aspects of Biofilms and Drinking Water. Boca Raton, FL: CRC Press, 2000; 61.

4. LeChevallier M, Cawthon C, Lee R. Factors promoting survival of bacteria in chlorinated water supplies. Appl Environ Microbiol 1998;54:649.

L'environnement est en perpétuel changement et il n'est désormais plus possible de dire que nos sources d'approvisionnement en eau sont pures ou qu'elles le resteront. On compte aujourd'hui approximativement 6,2 milliards d'individus sur la planète qui, selon les experts, ne peut en supporter au maximum que 4 milliards. Les déchets industriels, humains et agricoles ne cessent d'augmenter. On les retrouve dans les nappes phréatiques, créant ainsi un risque de contamination bactérienne, virale et chimique. De nouveaux pathogènes mortels comme E.coli 0157:H7 font leur apparition et menacent nos réserves en eau. En Ontario comme ailleurs au Canada, de 30 à $40 \%$ des puits privés en général ne respectent pas les normes de potabilité de l'eau. ${ }^{2}$ L'eau est une ressource commune qui doit être réglementée en tant que telle; autrement dit, tant son utilisation privée que publique doit être prise en considération dans sa gestion globale.

que de penser que cela exige un contrôle permanent, la formation des personnels qui en sont responsables et un suivi constant.

Dans ce numéro de la RCSP, l'article relatif à l'enquête sur l'eau potable en ColombieBritannique menée en $1997-98^{1}$ va dans le sens des inquiétudes exprimées lors des enquêtes de Walkerton et North Battleford sur les épidémies de maladies d'origine hydrique. On peut citer entre autres : l'absence de source d'approvisionnement en eau protégée, les sources potentielles de pollution des bassins hydrographiques, l'absence de stérilisation primaire des eaux, le manque de programmes de formation des personnels dans plus de la moitié des installations de traitement de l'eau, et la contamination possible des nappes phréatiques à cause de puits désaffectés.

Médecin hygiéniste du service de santé Grey Bruce, Owen Sound (Ontario)

JANUARY - FEBRUARY 2002

\section{Les problèmes actuels}

On a découvert en 1982 l'E.coli 0157:H7. Ce nouveau pathogène, essentiellement transmis par le bétail en Amérique du Nord, se retrouve de plus en plus dans la chaîne alimentaire et, comme l'a montré la catastrophe de Walkerton, lorsque les conditions sont réunies, ce pathogène peut contaminer un système d'épuration d'eau. L'E. coli 0157:H7 ne sera probablement 
pas le dernier des nouveaux pathogènes à menacer notre eau potable; c'est la raison pour laquelle il est de la plus haute importance de mettre en oeuvre des programmes de formation à l'intention des personnels responsables de la gestion de l'eau ainsi qu'un programme permanent d'actualisation de cette formation pour prendre en compte les derniers développements technologiques et les nouvelles menaces pour la santé. Les responsables des services des eaux doivent être en mesure d'échanger leurs expériences et de tirer les leçons des épidémies d'origine hydrique.

Un grand nombre de municipalités ont des systèmes de distribution des eaux qui ne datent pas d'hier. Les vieilles canalisations, l'absence de technologies modernes de traitement, des protocoles de vérification de la qualité de l'eau inadaptés, ainsi que la formation insuffisante des personnels concourent à une plus grande probabilité de catastrophe hydrique. Toutes ces carences coûteront cher; il faudra un très grand courage et beaucoup de volonté politique pour s'attaquer à ces questions. Il faudra convaincre le public du besoin de débloquer des fonds suffisants et l'informer du coût réel des infrastructures et des opérations de surveillance et d'entretien nécessaires pour garantir la potabilité de l'eau.

Les vieux systèmes se caractérisent souvent par un épaississement du film biologique dans les canalisations. Ces mucelages ou films biologiques sont constitués de cellules immobilisées sous la surface et fréquemment enchâssées dans une matrice biologique polymère d'origine microbienne. ${ }^{3}$ On est encore loin d'une définition des films biologiques en raison de leur grande diversité. Dit plus simplement, le film biologique qui se trouve dans les canalisations d'eau est constitué par une sorte de boue accumulée et composée de déchets provenant de la corrosion des canalisations ainsi que de colonies de bactéries, de virus et d'algues. Les recherches sur les films biologiques sont à la fois récentes et très intéressantes. Les bactéries présentes dans les films biologiques se structurent et se caractérisent par des propriétés uniques en leur genre. L'E. coli 0157:H7 par exemple, est une bactérie qui est jusqu'à 2400 fois plus résistante au chlore dans les mucelages que dans l'eau courante. ${ }^{4}$ Une fois constitués, les films biologiques sont difficiles à enlever. Attendez-vous à entendre beaucoup plus parler des films biologiques dans les mois et les années à venir.

La vérification de la qualité de l'eau coûte cher. Pas nécessairement parce que les procédés sont onéreux en soi mais bien plutôt en raison des vérifications hebdomadaires multiples qui sont nécessaires pour garantir que les systèmes d'approvisionnement en eau potable fonctionnent comme il faut, ainsi que pour déceler les nouvelles possibilités de contamination éventuelle. En Ontario, en 1996, la vérification de la qualité de l'eau potable a été confiée à des laboratoires du secteur privé. Les municipalités en effet étaient de moins en moins disposées à prendre en charge l'augmentation des coûts des opérations et il apparaît que certaines opérations ont été réduites, voire éliminées, pour cette raison. En outre, les services de santé publique ont perdu les contacts étroits qu'ils avaient avec les laboratoires gouvernementaux autrefois chargés de ces vérifications.

Il faut ouvrir un débat sur le rôle des gouvernements dans la protection de la santé et de la sécurité du public. Je suis personnellement d'avis que l'on a sabré à un point tel dans les services publics qu'aujourd'hui la sécurité du public n'est plus assurée. À l'évidence, la responsabilité par excellence des pouvoirs publics devrait être la protection de la santé et de la sécurité de la population. Il serait ironique d'assurer la compétitivité du Canada sur le marché mondial au prix d'une diminution des mesures de sécurité publique entrầnant un risque pour la population active de notre pays.

\section{Les scénarios à venir}

La prévention est capitale en matière d'eau potable. Quand un test permet de détecter que l'eau est contaminée, il est déjà beaucoup trop tard car le public a déjà bu l'eau contaminée et court un risque. C'est la raison pour laquelle les sources d'eau potable doivent être sûres, que les systèmes d'approvisionnement doivent être équipés de dispositifs d'alerte et de contrôle, et que des systèmes de secours et de traitement adéquats doivent être mis en place.

Il faut partir de l'hypothèse que nous ne devons pas déverser nos déchets dans l'eau et qu'il nous faut trouver des solutions pour que tel ne soit jamais le cas.

Deux nouveaux livres viennent de paraître sur ce sujet. Il s'agit des livres de Mark De Villiers et de Laurie Garrett intitulés respectivement Water et Betrayal of Trust: The Collapse of Global Public Health. L'ouvrage de De Villiers passe en revue la situation de l'eau dans le monde. Il constate qu'il y a trop peu d'eau potable pour une population trop nombreuse. Des conflits risquent d'éclater autour des questions relatives à la propriété de l'eau potable et à son accès. En outre, nous sommes en train de polluer à une vitesse croissante l'eau potable existante. L'ouvrage de Garrett montre comment on accorde de moins en moins de moyens à la santé publique partout dans le monde. L'auteure traite des épidémies qui en découlent ainsi que des risques désormais bien présents en raison de la faiblesse des investissements publics dans les interventions et les activités de surveillance élémentaires de la santé publique.

En résumé, en raison d'un ensemble de facteurs, nous ne pouvons désormais plus avoir confiance dans nos sources d'approvisionnement en eau potable. L'eau potable est la pierre angulaire de la santé publique. Le monde est en train de changer et il nous faut resensibiliser le public et les gouvernements à l'importance de disposer de bons systèmes de distribution de l'eau, de former correctement les personnels des services des eaux, de renforcer le rôle de la santé publique dans la surveillance et les interventions en cas de problèmes, et de protéger nos bassins hydrographiques. Il faut convaincre les gouvernements de la nécessité d'instaurer un équilibre entre l'encouragement des pratiques commerciales et la protection de la santé et de la sécurité des citoyens. Enfin, il faut se pencher sur les raisons qui nous amènent à déverser nos déchets dans l'eau. Si nous persistons dans cette voie, cela ne fera que nuire davantage à la qualité de l'eau potable déjà nettement mise à mal. 